\title{
Combined effects of precipitation and nitrogen deposition on native and invasive winter annual production in California deserts
}

\author{
Leela E. Rao $\cdot$ Edith B. Allen
}

Received: 4 May 2009 / Accepted: 9 November 2009 / Published online: 5 December 2009

(C) The Author(s) 2009. This article is published with open access at Springerlink.com

\begin{abstract}
Primary production in deserts is limited by soil moisture and $\mathrm{N}$ availability, and thus is likely to be influenced by both anthropogenic $\mathrm{N}$ deposition and precipitation regimes altered as a consequence of climate change. Invasive annual grasses are particularly responsive to increases in $\mathrm{N}$ and water availabilities, which may result in competition with native forb communities. Additionally, conditions favoring increased invasive grass production in arid and semi-arid regions can increase fire risk, negatively impacting woody vegetation that is not adapted to fire. We conducted a seeded garden experiment and a 5-year field fertilization experiment to investigate how winter annual production is altered by increasing $\mathrm{N}$ supply under a range of water availabilities. The greatest production of invasive grasses and native forbs in the garden experiment occurred under the highest soil $\mathrm{N}$ (inorganic $\mathrm{N}$ after fertilization = $2.99 \mathrm{~g} \mathrm{~m}^{-2}$ ) and highest watering regime, indicating these species are limited by both water and N. A classification
\end{abstract}

Communicated by Louis Pitelka.

Electronic supplementary material The online version of this article (doi:10.1007/s00442-009-1516-5) contains supplementary material, which is available to authorized users.

L. E. Rao · E. B. Allen

Center for Conservation Biology,

University of California, Riverside, CA 92521, USA

E. B. Allen

Department of Botany and Plant Sciences,

University of California, Riverside, CA 92521, USA

Present Address:

L. E. Rao $(\square)$

Air Resources Board, Emission Research Section,

No. 4, 9528 Telstar Avenue, El Monte, CA 91731, USA

e-mail: 1rao@arb.ca.gov and regression tree (CART) analysis on the multi-year field fertilization study showed that winter annual biomass was primarily limited by November-December precipitation. Biomass exceeded the threshold capable of carrying fire when inorganic soil $\mathrm{N}$ availability was at least $3.2 \mathrm{~g} \mathrm{~m}^{-2}$ in piñon-juniper woodland. Due to water limitation in creosote bush scrub, biomass exceeded the fire threshold only under very wet conditions regardless of soil $\mathrm{N}$ status. The CART analyses also revealed that percent cover of invasive grasses and native forbs is primarily dependent on the timing and amount of precipitation and secondarily dependent on soil $\mathrm{N}$ and site-specific characteristics. In total, our results indicate that areas of high $\mathrm{N}$ deposition will be susceptible to grass invasion, particularly in wet years, potentially reducing native species cover and increasing the risk of fire.

Keywords Non-native $\cdot$ Fuel load $\cdot$ Bromus $\cdot$ Schismus . Climate change

\section{Introduction}

Climate change models indicate that many regions will experience an increase in the severity of extreme climatic events such as droughts, heat waves, and floods (Solomon et al. 2007). These climate changes will cause vegetation distributions to shift, such as in California where the extent of arid grasslands is predicted to increase due in part to increased fire size and frequency (Lenihan et al. 2003). Many studies from arid and semi-arid regions have shown a linkage between climate and fire (Swetnam and Betancourt 1998; Grissino-Mayer and Swetnam 2000; Harris et al. 2008; Drury and Veblen 2008; Miller et al. 2009). Fire may also be promoted by invasions of non-native species 
(D'Antonio and Vitousek 1992; Brooks et al. 2004), which themselves are associated with increased disturbance, including climate change, land use change, and $\mathrm{N}$ deposition (Dukes and Mooney 1999). In western North America, invasion by non-native grasses has resulted in increased fire frequency and intensity (Zouhar et al. 2008). This so called "grass-fire cycle" occurs because the invasive grasses create a persistent and continuous fine fuel load that allows fire to carry between widely spaced shrubs (D'Antonio and Vitousek 1992; Brooks et al. 2004). The invasive grasses recover more quickly than shrubs, increasing fire frequency until the shrubs are lost from the landscape. This type-conversion has occurred in several ecosystems including sagebrush, coastal sage scrub, and creosote bush scrub (Minnich and Dezzani 1998; Menakis et al. 2003; Brooks and Matchett 2006; Zouhar et al. 2008).

An increase in fire size and frequency has been observed in the Sonoran and Mojave Deserts resulting in reduced shrub density and diversity (Brown and Minnich 1986; Brooks and Berry 2006; Hereford et al. 2006). Fires in these deserts often occur in years with below-average precipitation but that are preceded by 1-2 years of above-average rainfall (Swetnam and Betancourt 1998; GrissinoMayer and Swetnam 2000; Lenihan et al. 2003; Brooks and Matchett 2006). The years of high rainfall result in high production by native and invasive annuals thereby increasing the fine fuel load (Brown and Minnich 1986). Arid land winter annuals have also been found to be sensitive to within-season precipitation timing, which differentially affects germination of invasive grasses and native forb species (Beatley 1974; Brooks 1999; Lundholm and Larson 2004; Sher et al. 2004).

While several large native annuals produce persistent fuel beds (Minnich 2008), the fuel components of greatest concern are invasive annual grasses red brome (Bromus madritensis), cheatgrass (Bromus tectorum), and Mediterranean split grass (Schismus barbatus and Schismus arabicus) that may increase in productivity in years of high rainfall (Brooks 1999; Brooks 2003; Salo 2004; Brooks and Minnich 2006). No threshold of fine fuels has been determined for desert biomass, although thresholds for fine fuels needed in grass-dominated systems are estimated to be 70$150 \mathrm{~g} \mathrm{~m}^{-2}$ (Anderson 1982; Scifres and Hamilton 1993; Fenn et al. 2003a). In the desert this range is more likely to be reached under high invasive grass abundance because grass litter does not disarticulate as rapidly as native forb litter (Brooks and Minnich 2006). Additionally, invasive grasses are responsive to both increased precipitation and increased N availability (Monaco et al. 2003; Fenn et al. 2003a; Salo et al. 2005).

After precipitation, $\mathrm{N}$ is considered most limiting to plant production in arid and semi-arid regions (Hooper and Johnson 1999). In arid regions downwind of major urban or agricultural centers, dry $\mathrm{N}$ deposition is increasing and is likely influencing plant communities through fertilization effects (Brooks 2003; Fenn et al. 2003b; Allen et al. 2009; Rao et al. 2009). The co-limitation of production by $\mathrm{N}$ and water suggests that the build-up of fine fuels sufficient to carry wildfires would most likely occur when both $\mathrm{N}$ deposition and above-average precipitation are present. Thus, the hypothesis addressed by this study is: $\mathrm{N}$ and precipitation interact such that the biomass produced by annual vegetation exceeds the fire threshold more frequently under $\mathrm{N}$ deposition. We tested the hypothesis using a seeded garden experiment and a multi-year (2004-2008) field fertilization of natural vegetation to evaluate the interactions between $\mathrm{N}$ fertilization and water availability on biomass production. By using classification and regression tree analysis (CART) on the long-term fertilization experiment results, we were able to examine the data for thresholds of soil $\mathrm{N}$ and consider the implications of uncertainty regarding fine fuel thresholds. Additionally, we examined the response of total annual production, native forb cover, and invasive forb cover to changes in precipitation timing to better determine the effects of within-season precipitation variability on production and winter annual community composition.

\section{Materials and methods}

\section{Garden experiment}

We established a seeded garden experiment to evaluate the growth response of an invasive, non-native grass $(B . \mathrm{mad}$ ritensis) and a native forb (Amsinckia tessellata) to three soil $\mathrm{N}$ levels and three precipitation regimes. $B$. madritensis and $A$. tessellata were chosen for this experiment because the field garden was located at a high-elevation site (1,047 $\mathrm{m}$ ) adjacent to Joshua Tree National Park (JTNP) in the Mojave Desert (Yucca Valley, CA; $34^{\circ} 7^{\prime} 34^{\prime \prime} \mathrm{N}$, $\left.116^{\circ} 24^{\prime} 59^{\prime \prime} \mathrm{W}\right)$ where these two species are most often implicated in providing critical biomass thresholds to carry fires (Brooks 1999). The garden site was on the same granitic parent material as occurs widely across JTNP and the region. Selected soil characteristics are listed in Table 1.

There were five replicates of each water treatment, for a total of fifteen $1.7 \times 2.5$-m plots that were subdivided into six $0.65 \times 0.6-\mathrm{m}$ subplots with a $20-\mathrm{cm}$ buffer around each subplot. Three subplots were planted with A. tessellata and three subplots with $B$. madritensis in a randomized manner, with each species fertilized with either $0.5,3.0 \mathrm{~g} \mathrm{~N} \mathrm{~m}^{-2}$, or left unfertilized as a control. Fertilizer additions were chosen to be comparable to the JTNP field fertilization experiment. We took one 8-cm-deep soil core from each subplot prior to fertilization for extraction with $1 \mathrm{M} \mathrm{KCl}$ and colorimetric determination of $\mathrm{NO}_{3}^{-}$and $\mathrm{NH}_{4}^{+}$(Technicon 
Table 1 General soil characteristics for the garden and field fertilization of natural vegetation experiments

\begin{tabular}{llllllll}
\hline & $\begin{array}{l}\text { Sand-silt-clay } \\
(\%)\end{array}$ & $\begin{array}{l}\text { Rock and } \\
\text { gravel }(\%)\end{array}$ & $\begin{array}{l}\text { Total soil } \\
\mathrm{N}\left(\mathrm{g} \mathrm{m}^{-2}\right)\end{array}$ & $\begin{array}{l}\text { Extractable P } \\
(\mathrm{ppm})^{\mathrm{a}}\end{array}$ & $\mathrm{pH}$ & $\begin{array}{l}\text { Bulk density } \\
\left(\mathrm{g} \mathrm{cm}^{-3}\right)\end{array}$ & $\begin{array}{l}\mathrm{N} \text { deposition } \\
\left(\mathrm{kg} \mathrm{ha}^{-1}\right)^{\mathrm{b}}\end{array}$ \\
\hline $\begin{array}{l}\text { Garden } \\
\text { Joshua Tree National Park }\end{array}$ & $17.1(0.8)^{\mathrm{c}}$ & $13.3(0.8)$ & $8.5(0.4)$ & $6.96(0.03)$ & $1.64(0.01)$ & $\mathrm{NA}$ \\
PJ-low N & $74-22-3$ & $39.1(2.6)$ & $31.7(2.2)$ & $9.3(0.8)$ & $8.10(0.04)$ & $1.81(0.04)$ & 6.2 \\
PJ-high N & $88-11-1$ & $24.5(1.8)$ & $37.4(1.4)$ & $9.2(0.7)$ & $7.13(0.06)$ & $1.38(0.04)$ & 12.4 \\
CB-low N & $83-11-6$ & $28.6(1.6)$ & $17.7(0.05)$ & $2.7(0.2)$ & $7.92(0.01)$ & $1.63(0.03)$ & 3.8 \\
CB-high N & $88-10-2$ & $25.3(0.9)$ & $31.6(1.1)$ & $6.7(0.4)$ & $7.10(0.01)$ & $1.61(0.02)$ & 6.6 \\
\hline
\end{tabular}

Means presented with SEs in parentheses where available. $P J$ Piñon-juniper woodland, $C B$ creosote bush. NA not applicable

a Olsen-P extraction method

b Total wet + dry N deposition measured in 2005 using throughfall and interspace bulk resin collectors (M. Fenn, personal communication)

${ }^{c}$ Gravel only, rocks $>2 \mathrm{~cm}$ excluded during sample collection

Instruments, Tarrytown, NY). After the first rain and before seed planting, $\mathrm{N}$ fertilizer was added as granular $\mathrm{NH}_{4} \mathrm{NO}_{3}$.

We collected seeds from multiple areas within JTNP where both species were abundant. Within 1 week of the first rain seeds were planted to achieve a density of 150 plants $\mathrm{m}^{-2}$. After establishment, average densities were 110 and 29 plants $\mathrm{m}^{-2}$ for B. madritensis and A. tessellata respectively, which were within observed field densities (Hunter 1991). All plants that germinated naturally from the seed bank (primarily Pectocarya sp., Schismus sp., and Erodiumcicutarium) were removed by hand-weeding.

Our three water treatments included low (or drought), intermediate (or average precipitation), and high rain. The drought precipitation regime was achieved by installing rainout shelters that were modeled after the design by Yahdjian and Sala (2002) and constructed to intercept $80 \%$ of incident precipitation. Shelter roofs were constructed from strips of clear corrugated plastic and were removable in order to reduce shading of treated and nearby plots. We installed $25-\mathrm{cm}$-deep plastic lined trenches around the plot perimeter to prevent movement of water into the plot. A gutter collected rainwater and channeled the water to a 38-1 storage unit. Collected rainwater was applied to the high-rainfall plots, which were also trenched and lined to prevent movement of water out of the plot. All plots contained $\mathrm{ECH}_{2} \mathrm{O}$ volumetric soil water sensors (Decagon Devices, Pullman, WA) that were field calibrated by relating actual volumetric water content to sensor millivolt readings.

Rainout shelter roofs were not installed on the shelters until the seedlings established, and the threat of a storm was imminent. Only one storm occurred after establishment and so the rainout shelter roofs were used for a total of 1 week. Because of a lack of rain during the late winter and early spring, water was added to the intermediate and high-rainfall plots. Yucca Valley tap water was used to water the plots and contained $3.5 \mathrm{mg} \mathrm{NO}_{3}^{-} 1^{-1}$ with non-detectable amounts of $\mathrm{NH}_{4}^{+}$. Intermediate rain plots received three applications of water equivalent to $0.25 \mathrm{~cm}$ of precipitation per application and high-rainfall plots received six applications of $0.84 \mathrm{~cm}$ of water. In total, the plots received 16,11 , and $9 \mathrm{~cm}$ of natural + artificial precipitation in the high-, intermediate-, and low-water treatment plots, compared to the 70 year mean \pm SD of $10 \pm 8 \mathrm{~cm}$ of winter precipitation as determined from a nearby weather station.

We harvested eight individual B. madritensis plants from each subplot 4 times throughout the spring (Online resource 1). Because of the small number of A. tessellata that germinated, an allometric relationship between plant width and height and plant weight was developed for each harvest period using a total of 15 individuals. The harvestperiod specific allometric equations were used to calculate the weight of eight individuals from each treatment for which height and width were measured. At the final sampling eight individual A. tessellata plants were harvested from each subplot. All plants were oven dried at $60^{\circ} \mathrm{C}$ to constant mass and weighed. Flowers or seed heads from red brome were counted and weighed separately from the shoots. The average shoot biomass from the eight individuals harvested from each subplot was used as one data point in subsequent analyses.

\section{Field fertilization of natural vegetation}

\section{Geography and climate}

We established fertilization plots at four sites within JNTP. Two sites were in creosote bush (CB) scrub located in the lower elevation Sonoran Desert $\left(33^{\circ} 49^{\prime} 52.2^{\prime \prime} \mathrm{N}\right.$, $\left.115^{\circ} 45^{\prime} 26.6^{\prime \prime} \mathrm{W} ; 33^{\circ} 56^{\prime} 36.5^{\prime \prime} \mathrm{N}, 116^{\circ} 23^{\prime} 44.3^{\prime \prime} \mathrm{W}\right)$. The other two sites were piñon-juniper woodland $(\mathrm{PJ})$ in the higher elevation Mojave Desert $\left(34^{\circ} 2^{\prime} 13^{\prime \prime} \mathrm{N}, 116^{\circ} 4^{\prime} 29.6^{\prime \prime} \mathrm{W}\right.$; 
$\left.34^{\circ} 0^{\prime} 48.7^{\prime \prime} \mathrm{N}, 116^{\circ} 18^{\prime} 39.9^{\prime \prime} \mathrm{W}\right)$. In each vegetation type one site was located on the western edge of the park, which was subjected to high levels of $\mathrm{N}$ deposition (high $\mathrm{N}$ ), and one site was located in the interior of the park where there were low levels of $\mathrm{N}$ deposition (low N; Allen et al. 2009). Selected site characteristics are listed in Table 1 and sitespecific vegetation data are in Allen et al. (2009), with general descriptions in Keeler-Wolfe (2007) and Schoenherr and Burk (2007).

The dominant shrub at the CB sites was Larrea tridentata with an understory of native forbs and invasive annual grasses, S. arabicus and S. barbatus (hereafter Schismus spp.). Total live shrub cover was $9.5 \pm 2.7$ and $18.1 \pm 3.8 \%$ for CB-low N and CB-high N, respectively. The dominant trees/shrubs at the PJ sites were Juniperus californica and Pinus monophylla with an understory of shrubs, native forbs and invasive annual grasses, $B$. madritensis, B. tectorum, and Schismus spp. Live tree + shrub cover was $20.8 \pm 0.9$ and $22.7 \pm 1.4 \%$ at PJ-low $\mathrm{N}$ and PJhigh N, respectively. Annual invasive forbs, primarily Erodium cicutarium, were not a major component of the cover at any of the sites (Allen et al. 2009).

Rain gauges were installed at each site in 2005. Determination of rain-year precipitation (1 October-30 September) prior to 2005 was made using the closest available weather station (http://www.ncdc.noaa.gov/oa/ncdc.html) and calibrated to site data using linear regression of daily data from 2 years of site and station data. Cumulative winter precipitation for each year in the study is presented in Fig. 1. The winter season precipitation (September-May) was between $45-160 \%$ of the long-term (70-year) average in all years and sites except for 2004-2005 and 2006-2007. The 20042005 rain year precipitation was $225-425 \%$ above the longterm average and was one of the wettest years on record. In contrast, the 2006-2007 rain year precipitation was 6-30\% of the long-term average and one of the driest years on record. During this year no germination occurred at any of the sites. CB-low N was similarly dry in 2005-2006, receiving a total of only $26 \mathrm{~mm}$ of rain during the winter, and as a result there was no germination during that year either.

\section{Experimental design}

We centered each plot on an individual tree or shrub, with the plot size determined by the shrub or tree size $(6 \times 6 \mathrm{~m}$ for creosote bush, $8 \times 8 \mathrm{~m}$ for juniper, and $10 \times 10 \mathrm{~m}$ for pine). Two levels of fertilizer were used, 0.5 and $3.0 \mathrm{~g} \mathrm{~N} \mathrm{~m}^{-2}$ year $^{-1}$, plus unfertilized controls. In the winter 2005, a lower fertilization treatment $\left(0.2 \mathrm{~g} \mathrm{~N} \mathrm{~m}^{-2} \mathrm{year}^{-1}\right)$ was added because the $0.5 \mathrm{~g} \mathrm{~N} \mathrm{~m}^{-2}$ year $^{-1}$ treatment had significant effects on biomass in the spring 2005 and we were interested in determining if a lower $\mathrm{N}$ threshold

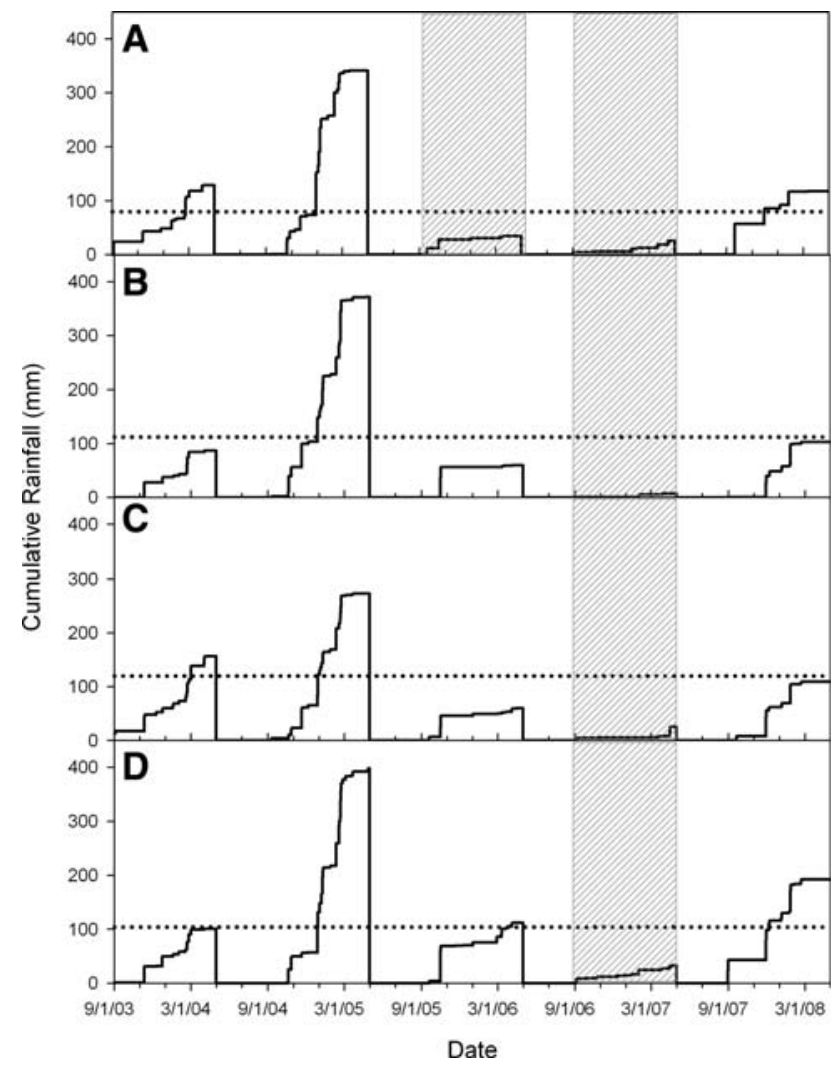

Fig. 1 Cumulative winter precipitation $(\mathrm{mm})$ for the years in which vegetation was sampled at the four Joshua Tree National Park sites: creosote bush (CB)-low N (a), CB-high $\mathrm{N}(\mathbf{b})$, piñon-juniper woodland (PJ)-low N (c), and PJ-high N (d). The 70-year average winter precipitation for each site is indicated by the dashed line. Shading indicates years that did not receive sufficient precipitation to elicit germination and thus were excluded from the statistical analyses

existed. The fertilization levels bracket the observed range of $\mathrm{N}$ deposition found in this region (Sullivan et al. 2001; Tonnesen et al. 2007). In addition, the high level of fertilization was chosen to be comparable to other desert fertilization studies where $3.0 \mathrm{~g} \mathrm{~N} \mathrm{~m}^{-2}$ year $^{-1}$ has induced responses by the invasive grasses (Brooks 2003). Ten replicates of each shrub or tree species were fertilized and selected across the landscape in a randomized block design, with the exception of PJ-low $\mathrm{N}$ where the limited availability of trees and shrubs resulted in nine blocks. At the PJ sites, both pine and junipers were fertilized with $0,0.5$, and $3.0 \mathrm{~g} \mathrm{~N} \mathrm{~m}^{-2}$ year $^{-1}$ in each block, but only juniper $0.2 \mathrm{~g} \mathrm{~N}$ $\mathrm{m}^{-2}$ year $^{-1}$ plots were added to each block in 2005 due to limited numbers of pines at these sites. Plots were fertilized with granular $\mathrm{NH}_{4} \mathrm{NO}_{3}$ each December beginning in 2002.

We sampled vegetation each spring (March-May) at the peak of production, which varied by site and year depending on temperature and precipitation. Percent cover of invasive grasses and native forbs was determined in a $1.0 \times 0.5-\mathrm{m}$ gridded quadrat placed outside the drip line of each shrub (i.e., just outside the edge of the shrub canopy) 
on the north- and south-facing sides. Biomass was calculated from the percentage cover data using equations developed for one $\mathrm{CB}$ site and one $\mathrm{PJ}$ site relating percent cover to biomass using $0.25 \times 0.5$-m clipped plots. Biomass relationships were determined in 2005 and 2008 for fertilized and unfertilized plots, with the 2008 data applied to all years except 2005 due to the very high amounts of precipitation received during the 2004-2005 growing season. Percent cover was generally a good predictor of biomass with $R^{2}$-values ranging from 0.77 to 0.97 (2005 regressions $n=11,2008$ regressions $n=21$ ). A relationship between percent cover at the drip line and the percent cover in the interspaces (i.e., the spaces outside the influence of the shrubs) was developed using 2008 cover data from PJ-high $\mathrm{N}$. Because interspace vegetation carries fire through the desert by creating a continuous fine fuel source between shrubs and is the basis for the fire thresholds, it was necessary to convert all drip line percent cover values to interspace cover estimates. Percent cover, measured in $1 \times 0.5$ $\mathrm{m}$ gridded quadrat in the interspaces of a subset of PJ plots was found to be 0.76 of the percent cover on the south side of the shrub. This conversion was applied to all sites and treatments in all years and biomass calculated from the interspace cover estimates.

Prior to fertilization, we took soil cores to a depth of $5 \mathrm{~cm}$ from interspace areas in all plots for extractable soil $\mathrm{N}$ analysis. Soils collected in 2003 and 2004 were extracted with $1 \mathrm{M} \mathrm{KCl}$ and analyzed colorimetrically for $\mathrm{NO}_{3}{ }^{-}$and $\mathrm{NH}_{4}{ }^{+}$(Technicon Instruments). Beginning in 2005, soils were sent to the DANR Analytical Laboratory for $\mathrm{NO}_{3}{ }^{-}$ and $\mathrm{NH}_{4}^{+}$determination based on published protocols (http://www.danranlab.ucdavis.edu/). Extractable soil N was converted to an aerial basis using average site rock content and bulk density measurements and summing the measured soil $\mathrm{N}$ with the $\mathrm{N}$ fertilizer added. In the cases of outliers or missing data, the mean value from all plots in a treatment was used in the statistical analyses.

\section{Statistics}

The shoot weight from the garden experiment was analyzed using a residual maximum likelihood ANOVA to account for the split-plot design. The ANOVA was run for each species and sampling period to determine the effect of $\mathrm{N}$, water availability, and the $\mathrm{N} \times$ water interaction on biomass using JMP version 7 (SAS Institute, Cary, NC). Significant effects were determined with post-hoc Tukey's honest significant difference test using an $\alpha=0.05$. All data were transformed as necessary to meet requirements for equal variance and normal distribution of error.

For the field fertilization of natural vegetation experiment, CART was conducted using JMP version 8 (SAS Institute, Cary, NC). We chose to use regression tree analysis due to its ability to handle non-linear combinations of predictor variables and identify thresholds (De'Ath and Fabricius 2000; Vayssieres et al. 2000). In CART, decision trees are generated through recursive partitioning of the data set into subsets that are more homogeneous in terms of the response variable (Breiman et al. 1984). Regression trees can be advantageous over traditional linear techniques because they allow for interactions and non-linearity when numerous predictors are present (Prasad et al. 2006). In addition, CART is robust with respect to outliers and does not require that the data be normally distributed (De'Ath and Fabricius 2000; Vayssieres et al. 2000).

For our CART analyses, $90 \%$ of the dataset was used for model development; we reserved $10 \%$ used for model validation. Time periods when no germination occurred due to lack of rain (Fig. 1, shaded areas) were excluded from the analyses. The method of recursive partitioning we used was maximize the split statistic, missing data were filled with the closest value, and the minimum number of samples per terminal node was set at five. The model trees were overgrown and pruned to size using 15 sets of tenfold cross-validations and the 1-SE rule to determine the optimal tree size (Breiman et al. 1984; De'Ath and Fabricius 2000). Predictor and response variables used in the CART analyses are presented in Table 2. Trees were created for each vegetation type (CB and $\mathrm{PJ})$ as well as for each site individually using plot estimates of interspace biomass, invasive grass cover, and native forb cover. In the trees created for the vegetation types, Site was included as a variable to account for unmeasured differences between the sites such as soil texture and landscape characteristics. The goodness of fit for the regression tree models was evaluated using an $R^{2}$ for the calibration and validation data sets, and the model variance explained by each variable was calculated.

\section{Results}

\section{Garden experiment}

The 2007-2008 winter rain season in the Yucca Valley region was characterized by four precipitation events; one each in December and January, and two in February (Online resource 1). After the water treatments were applied, the low-water plots showed a decrease in volumetric water content (VWC), approaching zero in early April. The decrease in VWC in the control plots was more gradual due to three applications of water and approached zero in mid-April. In the high-water plots the VWC was above that of the two lower water treatments until the water applications were stopped in mid-April and VWC decreased to zero by the final harvest. 
Table 2 Variable descriptions used in regression tree analysis

\begin{tabular}{|c|c|c|}
\hline Variable & Type & Description \\
\hline Site & Predictor & $\begin{array}{l}\text { For vegetation type analyses only; identifies the site location } \\
\text { in each vegetation type (low } \mathrm{N} \text { or high } \mathrm{N})\end{array}$ \\
\hline Species & Predictor & For PJ only; identifies the species of tree or shrub about which the plot was located \\
\hline SOP & Predictor & Amount of precipitation that fell during September and October \\
\hline NDP & Predictor & Amount of precipitation that fell during November and December \\
\hline JFP & Predictor & Amount of precipitation that fell during January and February \\
\hline MAP & Predictor & Amount of precipitation that fell during March and April \\
\hline SoilN & Predictor & $\begin{array}{l}\text { Amount of soil } \mathrm{N} \text { measured prior to fertilization each winter }+ \text { the amount } \\
\text { of fertilizer added, converted to } \mathrm{g} \mathrm{m}^{-2}\end{array}$ \\
\hline Biomass & Response & $\begin{array}{l}\text { Total interspace biomass calculated from } \% \text { cover of invasive grasses and native forbs } \\
\text { measured outside the shrub dripline and multiplied by a reduction factor }\end{array}$ \\
\hline EGC & Response & $\begin{array}{l}\text { Average percent cover of invasive (exotic) grasses measured outside the dripline } \\
\text { of the north and south sides of shrubs }\end{array}$ \\
\hline NFC & Response & $\begin{array}{l}\text { Average percent cover of native forbs measured outside the dripline } \\
\text { of the north and south sides of shrubs }\end{array}$ \\
\hline
\end{tabular}

Inorganic soil $\mathrm{N}$ after fertilization and prior to planting was $0.95 \pm 0.02,1.54 \pm 0.04$, and $2.99 \pm 0.05 \mathrm{~g} \mathrm{~m}^{-2}$ in the control, 0.5 and $3.0 \mathrm{~g} \mathrm{~N} \mathrm{~m}^{-2}$ plots respectively. ANOVAs on biomass for A. tessellata at each harvest showed a significant effect of $\mathrm{N}$ throughout (1st, $P<0.0001$; 2nd, $P<0.0001$; 3rd, $P=0.002$; 4th, $P<0.0001)$, with water becoming significant at the second sampling period (1st, $P=0.11 ; 2$ nd, $P=0.02$; 3rd, $P=0.004 ; 4$ th, $P=0.0003$ ). At the second and third harvests there were no significant differences in plant size between the high- and low-water treatments. By the final harvest, the plants in the high-water treatment were significantly larger than those in the other two treatments. Throughout the growing season the individual A. tessellata plants were larger in the high-N plots than in the low-N and control plots, which were not significantly different from each other. In all water treatments the plants were largest at the final harvest, particularly in the high-N plots, due to the effect of bolting on individual biomass (Fig. 2a).

ANOVAs on biomass of $B$. madritensis at each harvest also showed a significant effect of $\mathrm{N}$ throughout (in all sam-

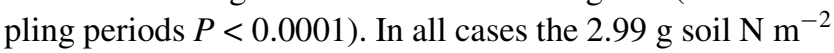
plots had larger plants, with no difference in plant size between 0.95 and $1.54 \mathrm{~g} \mathrm{~N} \mathrm{~m}^{-2}$. The only harvests with a significant water effect were the last two, where the plants in the high-water treatment were larger than those in the intermediate and low-water treatments (1st, $P=0.54 ; 2$ nd, $P=0.46$; 3rd, $P=0.0002$; 4 th, $P<0.0001)$. In all $\mathrm{N}$ treatments the plants reached the maximum size by second harvest in the low- and intermediate-water plots; in the highwater plots individuals continued to grow until the final harvest (Fig. 2b). No $\mathrm{N} \times$ water interactions were observed at any harvest for either species.
Field fertilization of natural vegetation

Precipitation during the study period varied between years and among sites each year (Fig. 1). This resulted in a large variation in precipitation amounts and timing over the study period for the two vegetation types. The regression tree analysis for total biomass in CB indicated that NovemberDecember precipitation (NDP) was the most important factor in determining how much biomass was produced (Table 3; Fig. 3). Biomass was above the fire threshold of $100 \mathrm{~g} \mathrm{~m}^{-2}$ when NDP $>28 \mathrm{~mm}$ and September-October precipitation $(\mathrm{SOP})>0.8 \mathrm{~mm}$. Soil $\mathrm{N}$ explained $1.8 \%$ of the model variation, and resulted in increased biomass in cases when there was low rainfall and soil $\mathrm{N}>0.28 \mathrm{~g} \mathrm{~m}^{-2}$. Soil $\mathrm{N}$ explained a smaller percentage of the variance in invasive grass $(1.5 \%)$ and native forb (1.4\%) regression trees. These trees indicated that there was a negative association of native forb cover with increased soil $\mathrm{N}$, such that the percent cover was greater when soil $\mathrm{N}<3.4 \mathrm{~g} \mathrm{~m}^{-2}$. Native forb cover was highest with large, early rainfall amounts (SOP $>57 \mathrm{~mm}$ and $\mathrm{NDP}>28 \mathrm{~mm}$ ). Invasive grass cover was maximized when soil $\mathrm{N}>0.9 \mathrm{~g} \mathrm{~m}^{-2}$ and winter rainfall was high [January-February precipitation $(\mathrm{JFP})>59 \mathrm{~mm}$ and NDP $>110 \mathrm{~mm}$ ].

Individual regression trees for native forb and invasive grass cover at the low- and high-N-deposition CB sites had fewer terminal nodes than those for the combined sites (Table 3). For both invasive grass and native forb cover at CB-low N, precipitation explained the majority of the model variance. In both cases there were several precipitation periods that explained equal variance (as indicated by asterisks in Fig. 3 and Online resources 2 and 3); the most frequently occurring variable from the cross-validations is 
Fig. 2 Average individual plant biomass (g per plant $\pm \mathrm{SE}$ ) for each harvest of Amsinckia tessellata (a) and Bromus madritensis (b) across the water and soil $\mathrm{N}$ treatments. At the end of the growing season the largest individuals were found in the high water, high-N (black bars) treatments. Asterisks indicate the most significant response

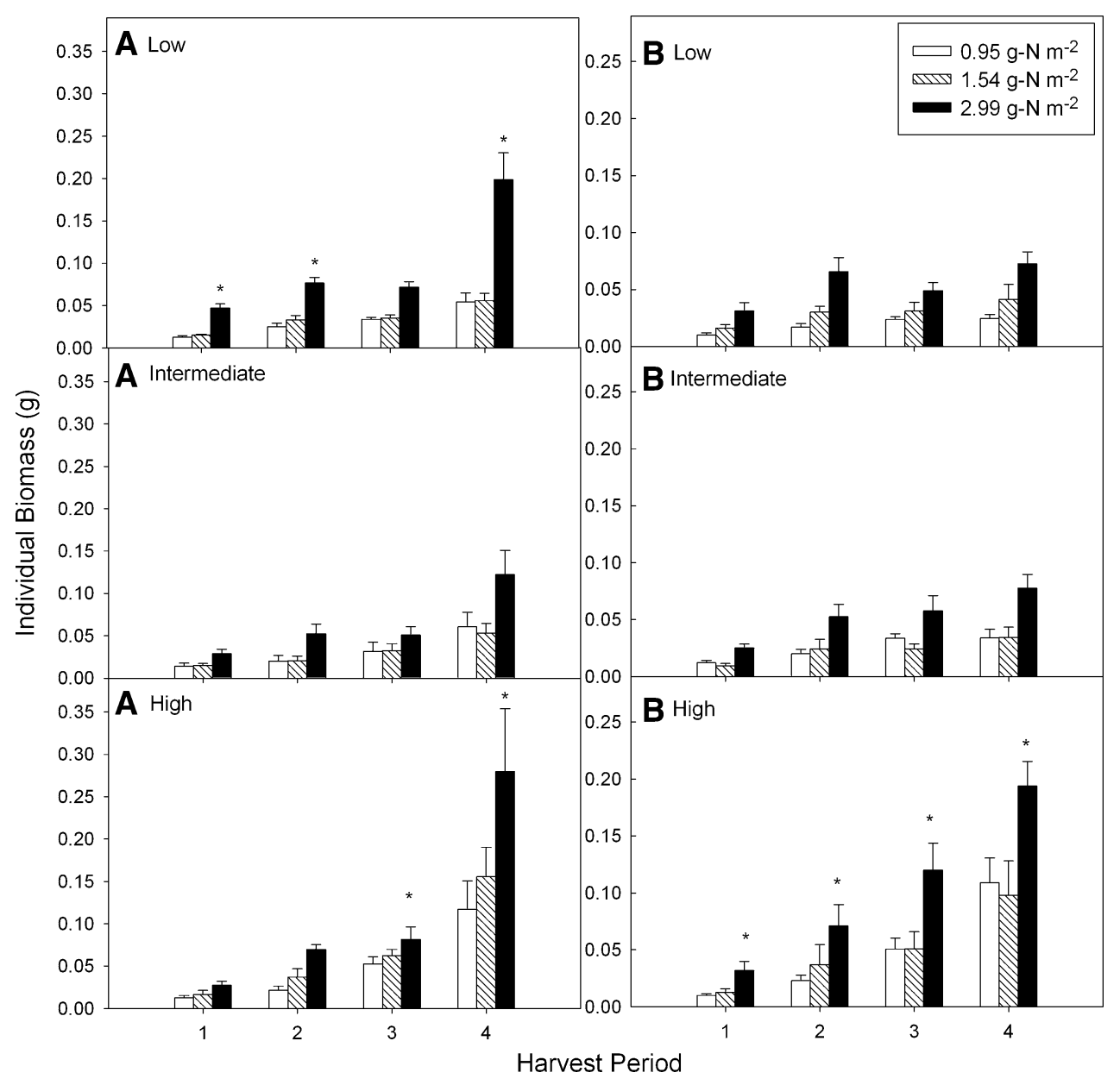

The site-specific PJ regression trees revealed that the greatest cover of invasive grasses occurred with JFP $>15 \mathrm{~mm}$ at PJ-low $\mathrm{N}$ and high fall rains (SOP $>50 \mathrm{~mm}$ ) and soil $\mathrm{N}$ (between 1.4 and $3.5 \mathrm{~g} \mathrm{~m}^{-2}$ ) at PJ-high $\mathrm{N}$ (Online resource 3 ). Overall, these models explained relatively little of the total variance in invasive grass cover (Table 3 ). Native forb cover at PJ-low $\mathrm{N}$ was more responsive to soil $\mathrm{N}$ than invasive grasses; the greatest cover of forbs occurred with between 3.4 and $4.0 \mathrm{~g} \mathrm{~m}^{-2}$ or greater than $0.5 \mathrm{~g} \mathrm{~m}^{-2}$ of soil $\mathrm{N}$ depending on the timing and amount of early and late season precipitation (Online resource 2). Native forb cover at PJ-high $\mathrm{N}$ was greatest under the influence of pine trees when soil $\mathrm{N}$ between 0.37 and $0.42 \mathrm{~g} \mathrm{~m}^{-2}$.

\section{Discussion}

Precipitation and $\mathrm{N}$ availability

The CART results indicate that the primary limiting factor for production at these arid sites is water, with the first split occurring on precipitation and explaining 77 and $69 \%$ of model variance in $\mathrm{CB}$ and $\mathrm{PJ}$, respectively. The greater explanatory power of precipitation at $\mathrm{CB}$ is likely because $0.67 \mathrm{~g} \mathrm{~m}^{-2}$. 
Fig. 3 Regression tree results on total biomass for each vegetation type. Predictor variables (see Table 2) in ovals, threshold value and percentage of model variance explained by that variable under the oval. Mean value of the response variable in rectangles, number of observations falling within that class shown under the mean. Biomass above the fire-carrying threshold indicated by shading. Asterisks indicate when multiple variables explained equal SS
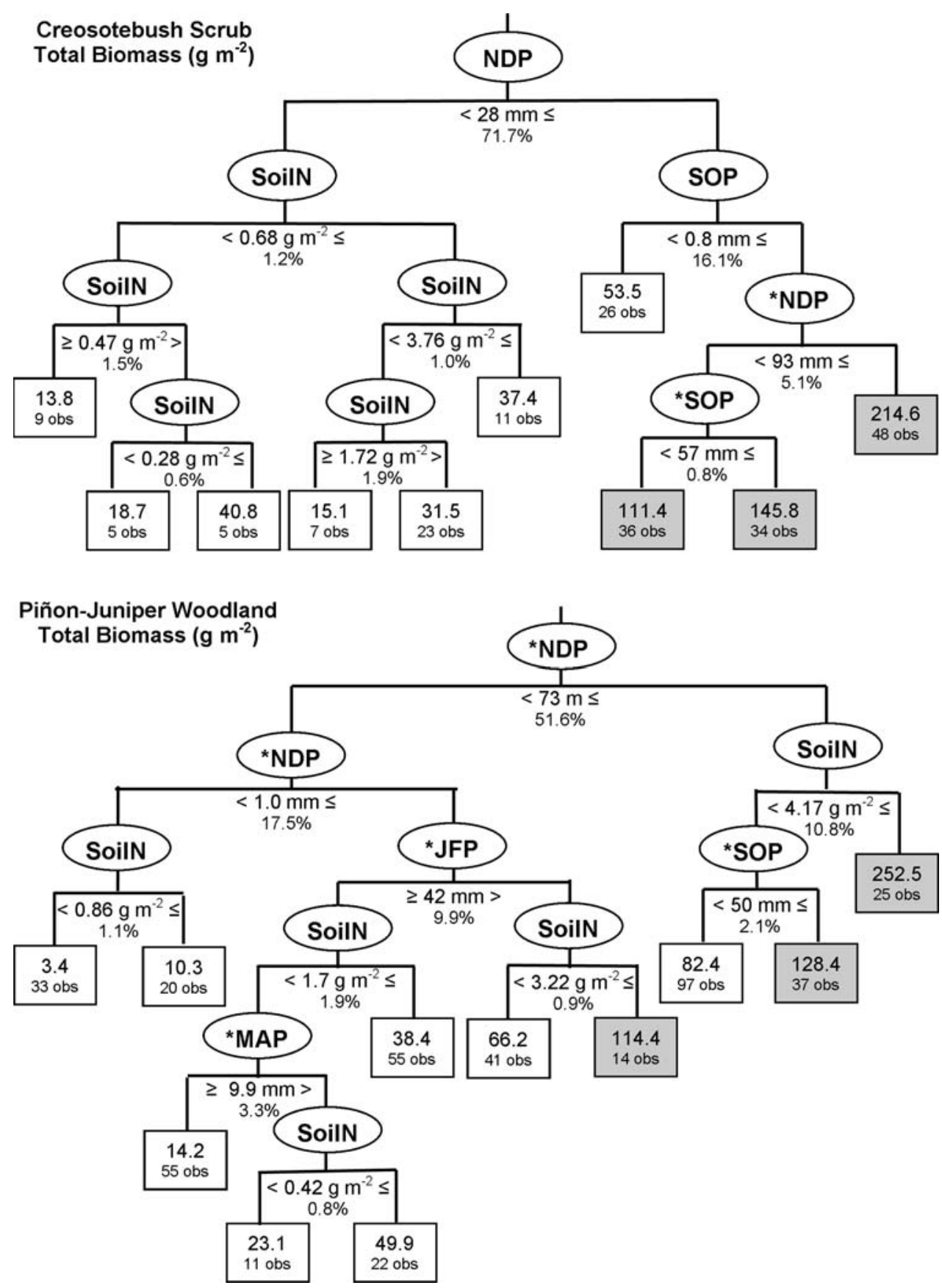

CB occurs in areas with less mean annual precipitation (Rowlands 1995); at our sites the mean winter precipitation in PJ was $17 \mathrm{~mm}$ greater than in $\mathrm{CB}$ over the study period. Studies in arid systems have shown that water availability is most limiting for annual production (Noy-Meir 1973; Beatley 1974; Patten 1978; Gutierrez et al. 1992; Brooks 2002). However, while some researchers have found that annual production exhibits secondary limitation by $\mathrm{N}$ (Whitford and Gutierrez 1989; Gutierrez et al. 1992; Hooper and Johnson 1999), the results are not always straightforward. Often the response to increased soil $\mathrm{N}$ is species or site specific, depending on antecedent soil $\mathrm{N}$ conditions (Gutierrez and Whitford 1987; Ludwig et al. 1989; Brooks 2003). In our CART models, soil $\mathrm{N}$ is a significant explanatory variable for both $\mathrm{CB}$ and PJ biomass, but only weakly so in CB (2\%) compared to PJ $(16 \%)$. Again, this is likely because CB is more water limited than PJ. However, we have a limited dataset (2004-2008) and do not include the severe drought year of 2007. Given the importance of precipitation timing on production and population dynamics (Went 1948; Bowers 1987; Brown 2002; Levine et al. 2008), additional years of data would be needed to fully understand the interacting effects of soil $\mathrm{N}$ and precipitation on production. 
Table 3 Summary of regression tree results

\begin{tabular}{|c|c|c|c|c|c|c|c|c|c|}
\hline Veg. Type & Sample & Response & $n-\mathrm{Cal}$ & $n$-Val & NV & NTN & $\mathrm{R}^{2} \mathrm{Cal}$ & $\mathrm{R}^{2} \mathrm{Val}$ & Total SS explained by each variable ${ }^{\mathrm{a}}(\%)$ \\
\hline $\mathrm{CB}$ & High and low $\mathrm{N}$ & Biomass & 204 & 36 & 3 & 9 & 0.76 & 0.78 & $\mathrm{NDP}=76.8, \mathrm{SOP}=16.9$, Soil $\mathrm{N}=1.8$ \\
\hline $\mathrm{CB}$ & High and low $\mathrm{N}$ & EGC & 204 & 36 & 4 & 5 & 0.77 & 0.85 & $\mathrm{JFP}=88.8, \mathrm{NDP}=7.0$, SoilN $=2.7, \mathrm{SOP}=1.5$ \\
\hline $\mathrm{CB}$ & High and low $\mathrm{N}$ & NFC & 203 & 36 & 3 & 6 & 0.76 & 0.67 & $\mathrm{NDP}=78.5, \mathrm{SOP}=19.2$, Soil $\mathrm{N}=1.4$ \\
\hline $\mathrm{CB}$ & Low $\mathrm{N}$ & EGC & 85 & 15 & 3 & 3 & 0.74 & 0.84 & $\mathrm{SOP}=88.5$, SoilN $=6.5, \mathrm{MAP}=5.1$ \\
\hline $\mathrm{CB}$ & Low $\mathrm{N}$ & NFC & 85 & 15 & 2 & 2 & 0.80 & 0.80 & $\mathrm{SOP}=94.6$, SoilN $=5.4$ \\
\hline $\mathrm{CB}$ & High $N$ & EGC & 119 & 21 & 2 & 2 & 0.62 & 0.55 & $\mathrm{NDP}=95.4, \mathrm{SOP}=4.6$ \\
\hline $\mathrm{CB}$ & High $\mathrm{N}$ & NFC & 118 & 21 & 3 & 4 & 0.77 & 0.67 & $\mathrm{NDP}=87.1, \mathrm{SOP}=8.8$, Soil $\mathrm{N}=4.0$ \\
\hline PJ & High and low $\mathrm{N}$ & Biomass & 410 & 71 & 5 & 10 & 0.62 & 0.61 & $\mathrm{NDP}=69.1$, SoilN $=15.6, \mathrm{JFP}=9.9, \mathrm{MAP}=3.3, \mathrm{SOP}=2.1$ \\
\hline PJ & High and low $\mathrm{N}$ & EGC & 410 & 71 & 4 & 4 & 0.65 & 0.64 & Site $=79.1, \mathrm{SOP}=15.1, \mathrm{NDP}=4.2$, SoilN $=2.1$ \\
\hline PJ & High and low $\mathrm{N}$ & NFC & 410 & 71 & 4 & 11 & 0.39 & 0.39 & $\mathrm{NDP}=58.3$, Soil $=23.1$, Site $=10.6, \mathrm{SOP}=7.9$ \\
\hline PJ & Low $\mathrm{N}$ & EGC & 199 & 35 & 3 & 3 & 0.24 & 0.18 & $\mathrm{JFP}=85.3, \mathrm{SOP}=10.3$, SoilN $=4.4$ \\
\hline PJ & Low $\mathrm{N}$ & NFC & 199 & 35 & 3 & 5 & 0.44 & 0.45 & $\mathrm{SOP}=82.8$, SoilN $=12.2, \mathrm{MAP}=4.9$ \\
\hline PJ & High $N$ & EGC & 210 & 37 & 2 & 6 & 0.39 & 0.48 & $\mathrm{SOP}=76.9$, SoilN $=23.1$ \\
\hline PJ & High $N$ & NFC & 210 & 37 & 3 & 8 & 0.40 & 0.17 & SoilN $=56.9, \mathrm{NDP}=39.4$, Species $=3.7$ \\
\hline
\end{tabular}

$n$-Cal Number of plots in calibration dataset

$n$-Val number of plots in validation dataset

$N V$ number of explanatory variables in final model

NTN number of terminal nodes in final model

${ }^{a}$ Percentage of total SS explained by each variable in the representative final tree, See Tables 1 and 2 for other abbreviations and variable definitions

An additional factor that may confound our results is that the four sites are spread throughout JTNP in areas with different soil textures, amounts of rock cover, and longterm patterns of precipitation and $\mathrm{N}$ deposition. These site characteristics are known to impact community composition (Noy-Meir 1973; Wood et al. 2005; Kelly and Goulden 2008), the effect of which is observed through the PJ CART analyses where Site is a significant explanatory variable of both exotic grass and native forb cover. In spite of differences between the sites, there are consistent results regarding the response of native forb cover to soil $\mathrm{N}$. Native forb cover is greatest at all sites except $\mathrm{PJ}$-high $\mathrm{N}$ when soil $\mathrm{N}$ is less than 3.8-4.0 $\mathrm{g} \mathrm{N} \mathrm{m}^{-2}$ (Online resource 2), suggesting that above this soil $\mathrm{N}$ level native forbs are either directly harmed or outcompeted by nitrophilous species such as invasive grasses (Brooks 2003; Salo et al. 2005). At PJhigh $\mathrm{N}$, the greatest percent cover of native forbs occurs under low-N conditions $\left(<0.4 \mathrm{~g} \mathrm{~m}^{-2}\right)$ and in the influence of pine trees. The second highest cover of native forbs at this site is under intermediate soil $\mathrm{N}$ levels, $1.5 \mathrm{~g} \mathrm{~m}^{-2}<\mathrm{N}<3.8 \mathrm{~g} \mathrm{~m}^{-2}$, which is consistent with the threshold identified at the other three sites. The garden experiment also indicates that native forbs benefit from inputs of $\mathrm{N}$ between 1.5 and $3 \mathrm{~g} \mathrm{~m}^{-2}$, supporting the findings from other studies showing that native forbs in arid environments are N limited (Romney et al. 1978; Mun and Whitford 1989; Salo et al. 2005).
Exotic grass cover is more influenced by precipitation than native forb cover (Online resource 3), particularly at PJ-low $\mathrm{N}$ and CB-high $\mathrm{N}$ where there is inherently low grass cover. When grass cover is high, soil $\mathrm{N}$ concentrations as low as $0.9 \mathrm{~g} \mathrm{~m}^{-2}$ promote increased grass cover but no threshold of soil $\mathrm{N}$ emerged as with the native forbs. It is unclear whether the lack of a soil $\mathrm{N}$ threshold is due to an inherent property of the exotic grasses or because soil sampling occurred at individual points, resulting in high withintreatment variability and obscuring threshold identification. Understanding the factors promoting grass invasion is particularly important given that exotic grasses are associated with increased fire frequency in the deserts due to their persistent standing litter on the landscape through the dry season when fire threat is greatest (Brown and Minnich 1986; Brooks and Minnich 2006).

Our CART analysis is also useful for investigating the factors influencing biomass production and fire thresholds in the desert. There is currently a great deal of uncertainty regarding the amount of fine fuel needed to carry fire through arid landscapes. Studies of fire thresholds in grass-dominated systems have shown that the amount of fine fuel needed to carry fire is between 70 and $150 \mathrm{~g} \mathrm{~m}^{-2}$ (Anderson 1982; Scifres and Hamilton 1993; Minnich and Dezzani 1998; Fenn et al. 2003a). As a first approximation, we set the fire threshold for both ecosystem types at $100 \mathrm{~g} \mathrm{~m}^{-2}$ and found that the conditions leading to bio- 
mass production above this threshold are high amounts of rain in $\mathrm{CB}$, and high amounts of rain combined with high amounts of soil $\mathrm{N}$ in PJ (Fig. 3). Although years with greater fine fuel buildup increase the fire risk in both vegetation types (Brown and Minnich 1986; Rogers and Vint 1987; Brooks and Minnich 2006), PJ is more prone to burning than $\mathrm{CB}$ due to greater amounts of woody fuels (Brooks and Matchett 2006; Brooks and Minnich 2006). Thus, it is likely that the fine fuel threshold is closer to the low range $\left(70 \mathrm{~g} \mathrm{~m}^{-2}\right)$ in $\mathrm{PJ}$ and the high range $\left(150 \mathrm{~g} \mathrm{~m}^{-2}\right)$ in $\mathrm{CB}$. When we re-evaluate the CART results with these adjusted fire thresholds, we find that the only case when the fire threshold is exceeded at CB is when SOP is greater than $1 \mathrm{~mm}$ and NDP is greater than $93 \mathrm{~mm}$. The precipitation record from the past 75 years indicates that this precipitation pattern occurred 17 times, primarily in the late 1930 s-1940s and the late 1960s to early 1980s. This is consistent with the findings of Brown and Minnich (1986) who determined that fires in CB increased during the late 1970s, which they attributed to increased rainfall and exotic grass invasion in that period.

Brooks and Matchett (2006) examined factors influencing fire spread in the Mojave Desert and showed that the high-elevation woodlands and desert montane zones show little change in the size distribution of fire in response to rainfall amounts because of the amount of woody biomass in these zones. In the middle elevation zone they found that native fuels are generally just below the threshold allowing fire spread and thus are influenced by increased precipitation. Our PJ sites are in between the high-elevation woodlands and mid-elevation zone examined by Brooks and Matchett (2006) indicating that there is likely a fine fuel threshold for our sites that may be as low as $70 \mathrm{~g} \mathrm{~m}^{-2}$. There are four cases when biomass exceeds this threshold; three are when NDP is greater than $73 \mathrm{~mm}$ and one is when precipitation is intermediate but soil $\mathrm{N}$ is high, greater than $3.2 \mathrm{~g} \mathrm{~m}^{-2}$. In the garden experiment invasive grass biomass was greater in all water treatments when soil $\mathrm{N}$ was $3 \mathrm{~g} \mathrm{~m}^{-2}$, although the greatest biomass was observed under the highest precipitation and N. Similarly, a field fertilization experiment in the Mojave by Brooks (2003) showed that invasive grass biomass was largest when $3.2 \mathrm{~g} \mathrm{~N} \mathrm{~m}^{-2}$ was added in the year with $>300 \%$ above-average December precipitation, whereas no effect was observed when that amount of $\mathrm{N}$ was added in a year with average December precipitation. Together these results indicate that, in average years, soil $\mathrm{N}$ must be greater than $3 \mathrm{~g} \mathrm{~m}^{-2}$ for the fire threshold to be reached. Studies of fire in other arid and semi-arid regions have linked fire frequency with wet years that were followed by periods of below-average precipitation (Swetnam and Betancourt 1998; Grassino-Mayer and Swetnam 2000; Harris et al. 2008). Thus, with the exception of areas under very high $\mathrm{N}$ deposition loads, PJ in transitional mid- to high-elevation zones may be unlikely to burn in the absence of a period of wet years.

\section{Precipitation timing}

One purpose of the CART analysis was to understand the influence of precipitation timing on invasive grass and native forb cover. Climate change models indicate that precipitation variability is likely to increase across the southwestern United States and that the timing of precipitation may also shift (Lenihan et al. 2003; Bell et al. 2004; Bell and Sloan 2006). Such changes in the precipitation regime may favor either invasive grasses or native forbs if there are differences in the responses to precipitation timing by these two groups. Germination studies have shown that the common invasive grasses at our sites tend to germinate rapidly with small inputs of rain and without strict temperature requirements (Beatley 1974; Gutterman 1994; Salo 2004). In contrast, native winter forbs have strict germination requirements, generally needing at least $25 \mathrm{~mm}$ of precipitation and cold nighttime temperatures (Juhren et al. 1956; Gutterman 1994; Levine et al. 2008). The exception is a small group of summer-germinating plants that flower during the following spring (Went 1948). In years of lateAugust early-September rains, individuals from this species group can grow very large and make up a significant portion of the biomass (Went 1948).

The CART model for CB native forb biomass indicates that NDP > $28 \mathrm{~mm}$ provides conditions favorable for native forb cover, with the greatest cover observed in combination with SOP $>56 \mathrm{~mm}$. These results lend support to the findings that fall precipitation of at least $25 \mathrm{~mm}$ allows desert native plants to germinate, and that under conditions of early fall precipitation summer-germinating spring-flowering annuals can greatly increase native cover. For CB invasive grasses, JFP and MAP have equal explanatory power for the first split, indicating that invasive grasses are favored not only by a wet winter, but an extended rainy season. Our garden experiment resulted in an extended growing season in the high-water plots since natural precipitation ended in late February. The results from this controlled experiment show that by prolonging the growing season, the individual biomass of $B$. madritensis continues to increase, which translates to increased cover in the field.

Unlike in CB, PJ native forb cover is more influenced by late fall (NDP) and early winter (JFP) rain, while invasive grasses are influenced by SOP in the high-N site and NDP/ JFP at the low-N site. The reason for the virtual flip in the seasonality effects on invasive grass and native forb cover between $\mathrm{CB}$ and PJ may be due to the influence of temperature. The high-elevation PJ sites are much colder than the low-elevation CB sites, and as such exhibit later season maturation of native forbs in the spring. Temperatures are rarely 
cold enough to result in decreased survival of native forb seedlings once they have germinated (Juhren et al. 1956), but having sufficient moisture in the late winter months appears to allow the rosettes to grow, resulting in larger individuals and total cover at peak. The invasive grass cover in our PJ sites is primarily governed by site effects, making it difficult to draw generalizations based on our data. Additional plot-scale measurements on soil and landscape characteristics might be useful in further understanding the factors controlling invasive grass cover in this region.

\section{Conclusion}

We combined a garden experiment, where the invasive grass B. madritensis and the native forb A. tessellata were grown in monoculture, with a multi-year field fertilization of natural vegetation experiment to examine the interaction between soil $\mathrm{N}$ and water availability on production of desert winter annuals. We found that while native forbs and invasive grasses are limited by water availability, the response to increased soil $\mathrm{N}$ is dependent on factors such as the degree of water limitation, site characteristics (e.g., soil texture, soil $\mathrm{C}$ ), and degree of grass invasion. However, our results also show that in some cases added soil $\mathrm{N}$ increases production above the fire threshold, thereby increasing the risk of fire in some polluted areas. In addition to increasing fire risk, increased soil $\mathrm{N}$ promoted invasive grasses and decreased native forb cover at some sites. These results provide further evidence that native forb and shrub communities, and the associated wildflower displays, may be threatened by nonnative grass invasions particularly in areas such as JTNP that are subjected to increased $\mathrm{N}$ deposition.

Acknowledgments This research was funded by the National Park Service PMIS no. 72123, National Science Foundation DEB 0421530, the Community Foundation of San Bernardino and Riverside Counties, and a grant from the University of California, Riverside Graduate Division. The manuscript was substantially improved by comments provided by C. Barrows and L. Santiago, as well as three anonymous reviewers. Thanks also to $\mathrm{M}$. Fenn for providing $\mathrm{N}$ deposition values, the Foote family for allowing L. E. R. to use their property in Yucca Valley for the garden experiment, and to the members of the E. Allen laboratory, especially Chris True and Robert Steers, for field and lab support.

Open Access This article is distributed under the terms of the Creative Commons Attribution Noncommercial License which permits any noncommercial use, distribution, and reproduction in any medium, provided the original author(s) and source are credited.

\section{References}

Allen EB, Rao LE, Steers RJ, Bytnerowicz A, Fenn ME (2009) Impacts of atmospheric nitrogen deposition on vegetation and soils in Joshua Tree National Park. In: Webb RH, Fenstermaker LF, Heaton JS, Hughson DL, McDonald EV, Miller DM (eds) The
Mojave Desert: ecosystem processes and sustainability. University of Nevada, Las Vegas

Anderson HE (1982) Aids to determining fuel models for estimating fire behavior. General technical report INT-122. USDA Forest Service Intermountain Forest and Range Experiment Station, Ogden, Utah. http://www.fs.fed.us/rm/pubs_int/int_gtr122.pdf

Beatley JC (1974) Phenological events and their environmental triggers in Mojave-Desert ecosystems. Ecology 55:856-863

Bell JL, Sloan LC (2006) $\mathrm{CO}_{2}$ sensitivity of extreme climate events in the Western United States. Earth Interact 10:1-17

Bell JL, Sloan LC, Snyder MA (2004) Regional changes in extreme climatic events: a future climate scenario. J Climate 17:81-87

Bowers MA (1987) Precipitation and the relative abundances of desert winter annuals: a six-year study in the northern Mojave Desert. J Arid Environ 12:141-149

Breiman L, Friedman JH, Olshen RA, Stone CG (1984) Classification and regression trees. Wadsworth, Belmont

Brooks ML (1999) Alien annual grasses and fire in the Mojave Desert. Madrono 46:13-19

Brooks ML (2002) Peak fire temperatures and effects on annual plants in the Mojave Desert. Ecol Appl 12:1088-1102

Brooks ML (2003) Effects of increased soil nitrogen on the dominance of alien annual plants in the Mojave Desert. J Appl Ecol 40:344353

Brooks ML, Berry KH (2006) Dominance and environmental correlates of alien annual plants in the Mojave Desert, USA. J Arid Environ 67:100-124

Brooks ML, Matchett JR (2006) Spatial and temporal patterns of wildfires in the Mojave Desert, 1980-2004. J Arid Environ 67:148164

Brooks ML, Minnich RA (2006) Southeastern deserts bioregion. In: Sugihara NG, Wagtendonk JWV, Shaffer KE, Fites-Kaufman J, Thode AE (eds) Fire in California's ecosystems. University of California, Berkeley, pp 391-414

Brooks ML, D'Antonio CM, Richardson DM, Grace JB, Keeley JE, DiTomaso JM, Hobbs RJ, Pellant M, Pyke D (2004) Effects of invasive alien plants on fire regimes. Bioscience 54:677-688

Brown G (2002) Community composition and population dynamics in response to artificial rainfall in an undisturbed desert annual community in Kuwait. Basic Appl Ecol 3:145-156

Brown DE, Minnich RA (1986) Fire and changes in creosote bush scrub of the Western Sonoran Desert, California. Am Midl Nat 116:411-422

D’Antonio CM, Vitousek PM (1992) Biological invasions by exotic grasses, the grass fire cycle, and global change. Annu Rev Ecol Syst 23:63-87

De'Ath G, Fabricius KE (2000) Classification and regression trees: a powerful yet simple technique for ecological data analysis. Ecology 81:3178-3192

Drury SA, Veblen TT (2008) Spatial and temporal variability in fire occurrence within the Las Bayas Forestry Reserve, Durango, Mexico. Plant Ecol 197:299-316

Dukes JS, Mooney HA (1999) Does global change increase the success of biological invaders? Trends Ecol Evol 14:135-139

Fenn ME, Baron JS, Allen EB, Rueth HM, Nydick KR, Geiser L, Bowman WD, Sickman JO, Meixner T, Johnson DW, Neitlich P (2003a) Ecological effects of nitrogen deposition in the western United States. Bioscience 53:404-420

Fenn ME, Haeuber R, Tonnesen GS, Baron JS, Grossman-Clarke S, Hope D, Jaffe DA, Copeland S, Geiser L, Rueth HM (2003b) Nitrogen emissions, deposition, and monitoring in the western United States. Bioscience 53:391-403

Grissino-Mayer HD, Swetnam TW (2000) Century-scale climate forcing of fire regimes in the American Southwest. Holocene 10:213-220

Gutierrez JR, Whitford WG (1987) Chihuahuan Desert annualsimportance of water and nitrogen. Ecology 68:2032-2045 
Gutierrez JR, Aguilera LE, Armesto JJ (1992) The Effects of water and macronutrients addition on aboveground biomass production of annual plants in an old field from a coastal desert site of NorthCentral Chile. Rev Chil Hist Nat 65:83-90

Gutterman Y (1994) Strategies of seed dispersal and germination in plants inhabiting deserts. Bot Rev 60:373-425

Harris S, Tapper N, Packham D, Orlove B, Nicholls N (2008) The relationship between the monsoonal summer rain and dry-season fire activity of northern Australia. Int J Wildland Fire 17:674-684

Hereford R, Webb R, Longpre C (2006) Precipitation history and ecosystem response to multidecadal precipitation variability in the Mojave Desert region, 1893-2001. J Arid Environ 67:13-34

Hooper DU, Johnson L (1999) Nitrogen limitation in dryland ecosystems: responses to geographical and temporal variation in precipitation. Biogeochemistry 46:247-293

Hunter R (1991) Bromus invasions on the Nevada test site-present status of B. rubens and B. tectorum with notes on their relationship to disturbance and altitude. Great Basin Nat 51:176-182

Juhren M, Went FW, Phillips E (1956) Ecology of desert plants. 4. Combined field and laboratory work on germination of annuals in the Joshua Tree National Monument, California. Ecology 37:318-330

Keeler-Wolfe T (2007) Mojave Desert scrub vegetation. In: Barbour MG, Keeler-Wolfe T, Schoenherr AA (eds) Terrestrial vegetation of California. University of California Press, Berkeley, pp 609-656

Kelly AE, Goulden ML (2008) Rapid shifts in plant distribution with recent climate change. Proc Natl Acad Sci USA 105:1182311826

Lenihan JM, Drapek R, Bachelet D, Neilson RP (2003) Climate change effects on vegetation distribution, carbon, and fire in California. Ecol Appl 13:1667-1681

Levine JM, McEachern AK, Cowan C (2008) Rainfall effects on rare annual plants. J Ecol 96:795-806

Ludwig JA, Whitford WG, Cornelius JM (1989) Effects of water, nitrogen and sulfur amendments on cover, density and size of Chihuahuan Desert ephemerals. J Arid Environ 16:35-42

Lundholm JT, Larson DW (2004) Experimental separation of resource quantity from temporal variability: seedling responses to water pulses. Oecologia 141:346-352

Menakis JP, Osborne D, Miller M (2003) Mapping the cheatgrasscaused departure from historical natural fire regimes in the Great Basin, USA. In: Omni PN, Joyce LA (eds) Proceedings: fire, fuel treatments, and ecological restoration U.S. Department of Agriculture, Forest Service, Rocky Mountain Research Station, Fort Collins, pp 281-287

Miller JD, Safford HD, Crimmins M, Thode AE (2009) Quantitative evidence for increasing forest fire severity in the Sierra Nevada and Southern Cascade Mountains, California and Nevada, USA. Ecosystems 12:16-32

Minnich RA (2008) California's fading wildflowers: lost legacy and biological invasions. University of California Press, Berkeley

Minnich RA, Dezzani RJ (1998) Historical decline of coastal sage scrub in the Riverside-Perris plain, California. Western Birds 29:366-391

Monaco TA, Johnson DA, Norton JM, Jones TA, Connors KJ, Norton JB, Redinbaugh MB (2003) Contrasting responses of intermountain west grasses to soil nitrogen. J Range Manage 56:282-290

Mun HT, Whitford WG (1989) Effects of nitrogen amendment on annual plants in the Chihuahuan Desert. Plant Soil 120:225-231

Noy-Meir I (1973) Desert ecosystems: environment and producers. Annu Rev Ecol Syst 4:25-51

Patten DT (1978) Productivity and production efficiency of an upper Sonoran Desert ephemeral community. Am J Bot 65:891-895

Prasad AM, Iverson LR, Liaw A (2006) Newer classification and regression tree techniques: bagging and random forests for ecological prediction. Ecosystems 9:181-199
Rao LE, Parker DR, Bytnerowicz A, Allen EB (2009) Nitrogen mineralization across an atmospheric nitrogen deposition gradient in Southern California deserts. J Arid Environ 73:92-930

Rogers GF, Vint MK (1987) Winter precipitation and fire in the Sonoran Desert. J Arid Environ 13:47-52

Romney EM, Wallace A, Hunter RB (1978) Plant response to nitrogen fertilization in the northern Mojave Desert and its relationship to water manipulation. In: West NE, Skujins JJ (eds) Nitrogen in desert ecosystems Dowden. Hutchinson and Ross, Stroudsburg, pp 232-243

Rowlands PG (1995) Regional bioclimatology of the California Desert. In: Latting J, Rowlands PG (eds) The California Desert: an introduction to natural resources and man's impact University of California. Riverside Press, Riverside, pp 95-134

Salo LF (2004) Population dynamics of red brome (Bromus madritensis subsp rubens): times for concern, opportunities for management. J Arid Environ 57:291-296

Salo LF, McPherson GR, Williams DG (2005) Sonoran desert winter annuals affected by density of red brome and soil nitrogen. Am Midl Nat 153:95-109

Schoenherr AA, Burk JH (2007) Colorado Desert vegetation. In: Barbour MG, Keeler-Wolfe T, Schoenherr AA (eds) Terrestrial vegetation of California. University of California Press, Berkeley, pp $657-682$

Scifres CJ, Hamilton WT (1993) Prescribed burning for brushland management: the south Texas example. Texas A \& M University Press, College Station

Sher AA, Goldberg DE, Novoplansky A (2004) The effect of mean and variance in resource supply on survival of annuals from Mediterranean and desert environments. Oecologia 141:353-362

Solomon S, Qin D, Manning M, Chen Z, Marquis M, Averyt KB, Tignor M, Miller HL (eds) (2007) IPCC, Climate change 2007: the physical scientific basis (contribution of Working Group I to the fourth assessment report of the Intergovernmental Panel on Climate Change). Cambridge University Press, Cambridge

Sullivan TJ, Peterson CL, Blanchard CL, Tanenbaum SJ (2001) Assessment of quality and air pollutant impacts in class I national parks of California. National Park Service-Air Resources Division, Washington

Swetnam TW, Betancourt JL (1998) Mesoscale disturbance and ecological response to decadal climatic variability in the American southwest. J Climate 11:3128-3147

Tonnesen GS, Wang Z, Omary M, Chien CJ (2007) Assessment of nitrogen deposition: modeling and habitat assessment. Report \# CEC-500-2005-032. California Energy Commission, PIER Energy-Related Environmental Research. http://www.energy.ca.gov/ 2006publications/CEC-500-2006-032/CE-500-2006-032.PDF

Vayssieres MP, Plant RE, Allen-Diaz BH (2000) Classification trees: an alternative non-parametric approach for predicting species distributions. J Veg Sci 11:679-694

Went FW (1948) Ecology of desert plants. 1. Observations on germination in the Joshua Tree National Monument, California. Ecology 29:242-253

Whitford WG, Gutierrez JR (1989) Effects of water and nitrogen supplementation on phenology, plant size, tissue nitrogen, and seed yield of Chihuahuan Desert annual plants. Southwest Nat 34:546549

Wood YA, Graham RC, Wells SG (2005) Surface control of desert pavement pedologic process and landscape function, Cima Volcanic field, Mojave Desert, California. Catena 59:205-230

Yahdjian L, Sala OE (2002) A rainout shelter design for intercepting different amounts of rainfall. Oecologia 133:95-101

Zouhar K, Smith JK, Sutherland S, Brooks ML (2008) Wildland fire in ecosystems: fire and nonnative invasive plants. General technical report. RMRS-GTR-42-vol. 6. U.S. Department of Agriculture, Forest Service, Rocky Mountain Research Station, Ogden 